\title{
Pengembangan Aplikasi Transaksi Penjualan Di Toko Dunia Laptop Dengan Menggunakan VB.Net 2010
}

\author{
Hardiansyah $^{1}$, Syahrul Ramadhan ${ }^{2}$, Suciyati $^{3}$ \\ *Coresponding Email: ${ }^{1}$ hardiansyaharahman3@gmail.com,
}

\begin{abstract}
Abstrak. Tujuan penelitian ini adalah (i) untuk mengembangkan aplikasi dalam proses transaksi jual beli di toko Dunia Laptop; (ii) mempermudah pendataan stokis barang yang ada maupun yang telah habis di toko Dunia Laptop; (iii) untuk menghasilkan nota otomatis dalam bentuk selembaran kertas. Jenis penelitian ini adalah pengembangan. Model pengembangan yang digunakan dalam pengembangan aplikasi transaksi penjualan dengan mengunakan VB.Net 2010 yaitu menggukan model Waterfall. Model Waterfall adalah suatu proses pengembangan perangkat lunak berurutan, di mana kemajuan dipandang sebagai terus mengalir ke bawah (seperti air terjun) melewati fase-fase perencanaan, pemodelan, implementasi (konstruksi), dan pengujian. Hasil penilaian uji kelompok besar terhadap 5 item barang di toko Dunia Laptop pada aplikasi transaksi penjualan berbasis VB.Net 2010 subtema judul dan proses transaksi mencapai rata-rata kelayakan 4,5 yang artinya aplikasi ini Sangat Baik (SB) digunakan. Berdasarkan rata-rata kelayakan pencapaian dari validitas ahli, uji skala kecil dan uji skala besar menujukkan bahwa aplikasi transaksi penjuakan di toko Dunia Laptop berbasis VB.Net 2010 sangat layak digunakan.
\end{abstract}

Kata Kunci: Transaksi Penjualan, VB.Net 2010

\section{PENDAHULUAN}

Dunia masa kini tengah dihadapkan pada persaingan teknologi yang semakin berkembang pesat dalam berbagai bidang, baik dalam bidang pendidikan maupun ekonomi yang menjadi faktor pendorong terciptanya berbagai ide yang kreatif untuk menciptakan suatu perangkat lunak (application) yang dapat meringankan tugas dan pekerjaan manusia pada umumnya. Dalam bidang ekonomi sendiri segala sesuatu yang berbasis teknologi sudah mulai dikembangkan sejak puluhan tahun yang lalu, seperti e-comerse yang digunakan untuk mempermudah transaksi jual beli barang secara online, aplikasi penjualan barang dengan tujuan mempermudah transaksi jual beli, dan berbagai macam produk-produk lainnya. Sehingga peneliti terdorong untuk melakukan sebuah penelitian dengan mengembangkan salah satu produk yaitu aplikasi transaksi penjualan sebagai sarana untuk mempermudah transaksi jual beli di salah satu toko penjualan yang berada di Kabupaten Bima yaitu toko Dunia Laptop yang masih menggunakan aplikasi sederhana dalam melakukan transaksi jual beli.

Dalam menjalankan aktifitas penjualannya toko Dunia Laptop mempunyai cukup banyak pelanggan yang dimana itu bisa dilihat dari omset toko Dunia Laptop yang mampu menghasilkan puluhan juta rupiah setiap bulannya dengan karyawan yang minim yang menimbulkan permasalahan dalam hal transaksi, karna hanya mengandalkan selembaran kertas kwitansi dan nota sebagai instrument pelayanan. Hal tersebut menjadi faktor utama yang menyebabkan kurangnya efisiensi dan efektifitas selama proses penjualan berlangsun. Dengan adanya pengembangan aplikasi transaksi penjualan di Dunia Laptop akan mampu mengatasi permasalahan yang terjadi pada toko Dunia Laptop dalam hal ini, proses transaksi penjualan, pendataan stokis barang, dan pembuatan nota yang secara otomatis dengan selebaran kertas.

\section{Aplikasi}

Aplikasi adalah software yang dibuat oleh suatu perusahaan komputer untuk mengerjakan tugas-tugas tertentu guna untuk memudahkan dan meringankan pekerjaan manusia baik di dunia industri atau dunia pendidikan (Dhanta, 2009). Menurut Nazrudin (2012) perangkat lunak aplikasi adalah suatu subkelas perangkat lunak komputer yang memanfaatkan kemampuan komputer langsung untuk 
melakukan suatu tugas yang diinginkan pengguna.

Aplikasi dalam penelitian ini ialah suatu perangkat lunak yang dibuat atau diciptakan untuk tujuan mempermudah pengguna dalam mengatasi permasalahan yang dihadapi dalam kehidupan sehari-hari.

\section{Transaksi Penjualan}

Menurut Assauri (2004) penjualan ialah sebagai kegiatan manusia yang mengarahkan untuk memenuhi dan memuaskan kebutuhan dan keinginan melalui proses pertukaran. Sedangkan menurut Nitisemito (1998) penjualan ialah semua kegiatan yang bertujuan untuk melancarkan arus barang dan jasa dari produsen ke konsumen secara efisien dengan maksud untuk menciptakan permintaan yang efektif.

Yang dimaksud penjualan dalam penelitian ini ialah suatu kegiatan atau proses yang bertujuan memperlancar pertukaran barang dan jasa yang dimiliki dengan pihak lain secara efisien dan efektif.

\section{Toko atau Pasar}

Pasar adalah sekumpulan pembeli dan penjual dari sebuah barang atau jasa tertentu (Mankiw, 2007). Pasar ialah suatu tempat bertemunya para penjual dengan pembeli atau sekelompok anggota masyarakat yang memiliki keinginan untuk melakukan transaksi jual beli barang atau jasa yang diinginkan (Handri Ma'aruf, 2005). Para pembeli sebagai sebuah kelompok yang menentukan permintaan terhadap produk dan para penjual sebagai kelompok yang menentukan penawaran terhadap produk (Fata, 2010).

Pasar dalam penelitian ini ialah suatu tempat yang digunakan untuk menyimpan dan mempromosikan sekaligus melakukan transaksi pertukaran barang dan jasa yang dibutuhkan oleh konsumen.

\section{VB.Net 2010 (Visual Basic Net 2010)}

Menurut Nursal (2007) menjelaskan tentang Visual Basic dalam bukunya "Panduan Visual Basic I", bahwa Microsoft Visual Basic yaitu aplikasi yang dijalankan dengan menggunakan sistem operasi windows yang juga merupakan hasil karya dari perusahaan Microsoft Corporatiaon. Sedangkan menurut Stefano (2014) dalam bukunya yang berjudul "Cara Membangun Sistem Informasi Mengunakan VB.Net dan Komponen
Dxperience" mengemukakan bahwa Visual Basic merupakan sebuah bahasa pemrograman yang menawarkan Intergrated Development Environment (IDE) visual untuk membuat program perangkat lunak berbasis operasi Microsoft Windows menggunakan model pemrograman (COM).

\section{MySQL}

MySQL adalah salah satu jenis database server yang sangat terkenal dan banyak digunakan untuk membangun aplikasi web yang menggunakan database sebagai sumber dan pengelolaan datanya (Junaedi, 2005). MySQL dapat juga diartikan sebagai perangkat lunak yang digunakan untuk membangun database yang sering digunakan di lingkungan linux. MySQL merupakan software open source yang berarti free untuk digunakan. Selain di lingkungan linux, MySQL juga tersedia di lingkungan windows (Sulhan, 2007).

\section{METODE PENELITIAN}

Model pengembangan yang digunakan dalam pengembangan aplikasi transaksi penjualan pada penelitian ini dengan mengunakan VB.Net 2010 yaitu model Waterfall. Model Waterfall adalah suatu proses pengembangan perangkat lunak berurutan, di mana kemajuan dipandang sebagai terus mengalir ke bawah (seperti air terjun) melewati fase-fase perencanaan, pemodelan, implementasi (konstruksi), dan pengujian.

Tahapan model Waterfall meliputi:

\section{Requirement (Analisis Kebutuhan)}

Dalam langakah ini merupakan analisa terhadap kebutuhan sistem. Pengumpulan data dalam tahap ini bisa melakukan sebuah penelitian, wawancara atau study literatur. Seseorang system analisis akan menggali informasi sebanyak-banyaknya dari user sehingga akan tercipta sebuah sistem komputer yang bisa melakukan tugas-tugas yang diinginkan oleh user tersebut. Tahapan ini akan menghasilkan dokumen user requirement atau bisa dikatakan sebagai data yang berhubungan dengan keinginan user dalam pembuatan sistem. Dokumen inilah yang akan menjadi acuan system analisis untuk menterjemahkan ke dalam bahasa pemrograman.

\section{Design System (Desain Sistem)}


Proses design akan menterjemahkan syarat kebutuhan ke sebuah perancangan perangkat lunak yang dapat diperkirakan sebelum dibuat koding. Proses ini berfokus pada: struktur data, arsitektur perangkat lunak, representation interface, dan detail (Algoritma) prosedural. Tahapan ini akan menghasilkan dokumen yang disebut software requirement. Dokumen inilah yang akan digunakan programmer untuk melakukan aktivitas pembuatan sistemnya.

\section{Coding dan Testing (Penulisan Sinkode Programe/Implemention)}

Coding merupakan penerjemahan desing dalam bahasa yang bisa dikenali oleh komputer. Dilakukan oleh programmer yang akan meterjemahkan transaksi yang diminta oleh user. Tahapan inilah yang merupakan tahapan secara nyata dalam mengerjakan suatu sistem. Dalam artian penggunaan komputer akan dimaksimalkan dalam tahapan ini. Setelah pengkodean selesai maka akan dilakukan testing terhadap sistem yang telah dibuat tadi. Tujuan testing adalah menemukan kesalahan-kesalahan terhadap system tersebut dan kemudian bisa diperbaiki.

\section{Integration dan Testing (Penerapan atau Pengujian Program)}

Tahapan ini bisa dikatakan final dalam pembuatan sebuah sistem. Setelah melakukan analisa, design dan pengkodean maka sistem yang sudah jadi dapat digunakan oleh user.

\section{Operation \& Maintenance (Pemeliharaan)}

Perangkat lunak yang susah disampaikan kepada pelanggan pasti akan mengalami perubahan. Perubahan tersebut bisa karena mengalami kesalahan karena perangkat lunak harus menyesuaikan dengan lingkungan (periperal atau system operasi) baru, atau karena pelanggan membutuhkan perkembangan fungsional.

\section{Teknik Analisis Data}

1. DataProses Pengembangan Produk

Data proses pengembangan produk aplikasi transaksi penjualan di toko Dunia Laptop dengan menggunakan VB. Net 2010 berupa data deskriptif, yaitu tinjauan dan saran dari ahli media sesuai dengan prosedur dan pengembangan yang dilakukan. Tahap awal penelitian pengembangan dilakukan dengan pengumpulan data mengenai proses transaksi yang ada pada toko Dunia Laptop, tahap selanjutnya penyusunan instrumen dan pengembangan produk.

2. Tahap terakhir adalah penilaian.

Produk ini divalidasi oleh ahli media, setelah divalidasi oleh ahli media kemudian direvisi sehingga diperoleh hasil revisi produk tahap I (bila ada). Media hasil revisi tahap I kemudian diujicobakan dengan cara digunakan oleh petugas atau pemilik toko Dunia Laptop. Produk yang telah melalui proses uji coba akan direvisi kembali (bila ada). Berdasarkan tahap-tahap tersebut, makan akan dihasilkan produk akhir pengembangan aplikasi transaksi penjualan di toko Dunia Laptop dengan menggunakan VB.Net 2010 untuk digunakan oleh toko Dunia Laptop.

3. Data kelayakan produk yang dihasilkan Data kelayakan produk yang dihasilkan, ditentukan melalui analisis hasil validasi ahli media, dan uji coba produk yang dilakukan oleh petugas atau pemilik toko selaku ahli materi. Data hasil validasi ahli materi dan ahli media dianalisis secar deskriftif. Langkah-langkahnya adalah sebagai berikut:

a. Mengubah penilaian dalam bentuk kualitatif menjadi kuantitatif dengan ketentuan sebagai berikut:

Tabel 1. Pedoman Penilaian Skor

\begin{tabular}{lc}
\multicolumn{1}{c}{ Data Kualitatif } & Skor \\
\hline Sangat Baik (SB) & 5 \\
\hline Baik (B) & 4 \\
\hline Cukup (C) & 3 \\
\hline Kurang (K) & 2 \\
\hline Sangat Kurang (SK) & 1 \\
\hline
\end{tabular}

b. Setelah data terkumpul, lalu menghitung skor rata-rata dengan rumus:

Keterangan:

$$
\mathrm{X}^{-}=\left(\sum \mathrm{x}\right) / \mathrm{N}
$$

$\mathrm{X}^{-}=$Rata-rata skor tiap komponen

$\sum \mathrm{x}=$ Jumlah Skor

$\mathrm{N}$ = Jumlah Indikator yang dinilai

c. Mengubah skor rata-rata menjadi nilai kualitatif dengan kriteria sebagai berikut:

Tabel 2. Konversi Data Kuantitatif ke Kualitatif 


\begin{tabular}{|c|c|c|}
\hline Rentang Skor & Rerata Skor & Kategori \\
\hline $\mathrm{X}>\overline{X_{l}}+1,8 \mathrm{x}$ sbi & $\mathrm{X}>4,2$ & Sangat Baik (SB) \\
\hline$\overline{X_{l}}+0,6 \mathrm{sbi}<\mathrm{X} \leq \overline{X_{l}}+1,8 \times$ sbi & $3,4<\mathrm{X} \leq$ & Baik (B) \\
& 4,2 & \\
\hline$\overline{X_{l}}-0,6 \mathrm{sbi}<\mathrm{X} \leq \overline{X_{l}}+0,6 \mathrm{x}$ sbi & $2,6<\mathrm{X} \leq 3,4$ & Cukup (C) \\
\hline$\overline{X_{l}}-1,8$ sbi $<\mathrm{X} \leq \overline{X_{l}}-0,6$ x sbi & $1,8<\mathrm{X} \leq$ & Kurang (K) \\
& 2,6 & \\
\hline $\mathrm{X} \leq \overline{X_{l}}-1,8 \mathrm{x}$ sbi & $\mathrm{X} \leq 1,8$ & Sangat Kurang (SK) \\
\hline
\end{tabular}

Keterangan:

$\begin{array}{lll}\text { Skor maksimal ideal } & =5 & \\ \text { Skor minimal ideal } & =1 & \\ \text { Skor Aktual } & =\mathrm{X} & \\ \text { Rata-rata ideal } & =\mathrm{X} \overline{\mathrm{t}} \\ \text { Simpangan baku ideal } & =\mathrm{sbi}\end{array}$

$\mathrm{X} \overline{\mathrm{t}}=1 / 2 \quad$ (Skor maksimal ideal + Skor minimal ideal)

$$
\begin{aligned}
& =1 / 2(5+1) \\
& =3
\end{aligned}
$$

Sbi $=1 / 6($ Skor maksimal ideal + Skor minimal ideal)

$$
=0,67 \quad=1 / 6 \quad(5+1)
$$

Penilaian pengembangan aplikasi transaksi penjuala di toko Dunia Laptop dengan menggunakan VB.Net 2010 ini ditentukan dengan nilai minimal B (Baik). Jadi jika nilai rerata dari ahli media dan ahli materi memperoleh nilai B (Baik) maka aplikasi transaksi penjualan di toko Dunia Laptop ini dinyakatan layak.

\section{HASIL DAN PEMBAHASAN}

Produk yang dikembangkan ini berupa aplikasi transaksi penjualan di toko Dunia Laptop dengan mengunakan VB.Net 2010 dan telah selesai dikembangkan. Dengan melalui tahap validasi ahli materi, ahli media dan beberapa kritik dan saran dari para Dosen Pendidikan Teknologi Informasi untuk memperoleh hasil produk yang layak digunakan sehingga aplikasi transaksi penjualan di toko Dunia Laptop dengan menggunakan VB.Net 2010 layak digunakan sebagai alat transaski yang efektif dan akurat.

Berikut adalah tampilan aplikasi transaksi penjualan di toko Dunia Laptop dengan mengunakan VB.Net 2010 yang telah divalidkan:

\section{Tampilan Menu Utama Aplikasi Transaksi \\ Penjualan}

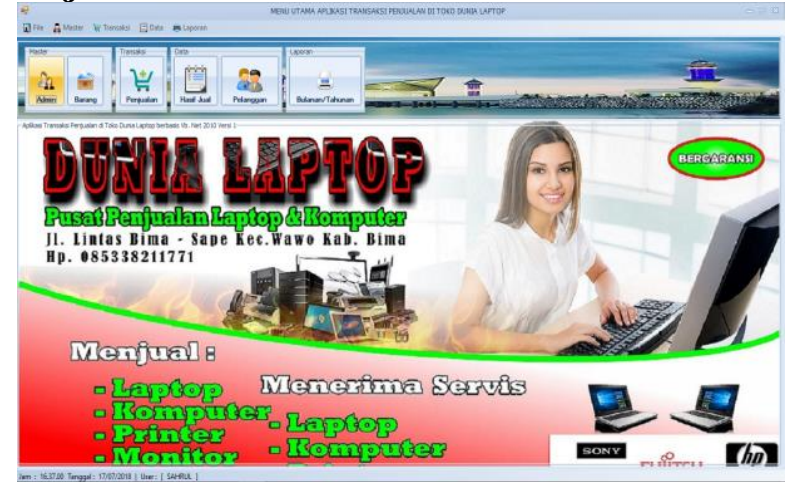

Gambar 1. Tampilan Menu Utama Aplikasi Transaksi Penjualan

1. File

Yang dimana menu ini yang menyediakan beberapa menu seperti:

a) Menu Login yaitu menu yang berfungsi untuk tempat pengguna memasukkan username dan password bila ingin menggukan aplikasi.

b) Menu Logout yaitu proses keluarnya petugas dari aplikasi penjualan setelah pengguna melakukan proses login.

c) Menu Keluar merupakan menu yang berfungsi untuk menutup semua aktifitas dari aplikasi.

2. Master

Yang dimana menu ini yang menyediakan beberapa menu seperti:

a) Menu Admin adalah menu yang digunakan untuk mendaftar atau menambah daripada petugas yang akan menggunakan aplikasi.

b) Menu Barang merupakan menu yang digunakan untuk pendataan barang, dan pengimputan data barang.

3. Transaksi adalah menu yang berguna untuk melakukan transaksi penjualan barang.

4. Laporan

Yang dimana menu ini yang menyediakan beberapa menu seperti:

a) Menu hasil penjualan ialah suatu menu yang berguna untuk melihat atau mengecek hasil penjualan yang sudah terjadi di toko Dunia Laptop.

b) Menu data pembeli adalah menu yang berguna untuk melihat data pembeli yang sudah melakukan transaksi pembelian di toko Dunia Laptop.

5. Cetak Laporan 
Yaitu menu yang digunakan untuk mencetak laporan hasil penjualan perbulan maupun pertahunnya.

\section{Tampilan Form Login}

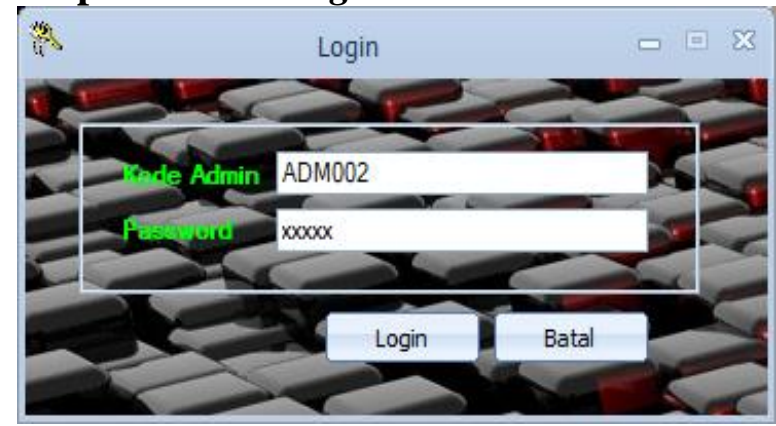

Gambar 2. Tampilan Form Login

Keterangan:

Form ini ada form yang digunakan oleh admin atau pengguna untuk login ke aplikasi agar dapat digunakan.

Tampilan Form Input Data Admin

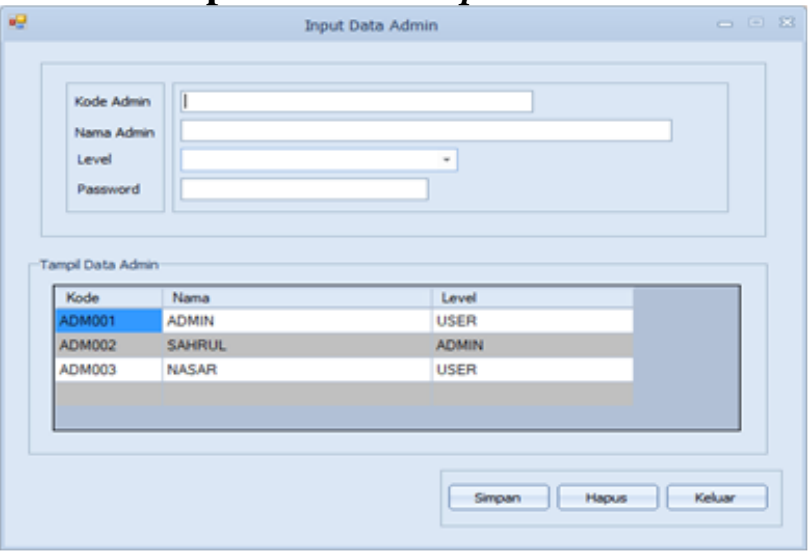

Gambar 3. Tampilan Form Input Data Admin Keterangan:

Form ini yang digunakan oleh admin untuk menambahkan data admin yang akan menggunakan aplikasi tersebut

Tampilan Form Input Barang

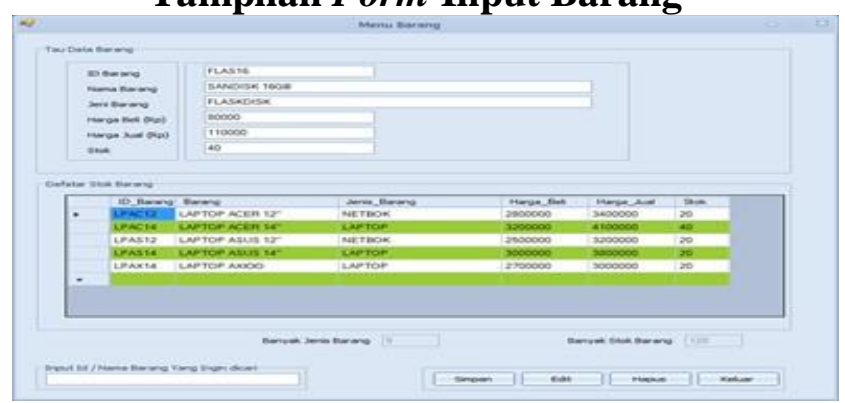

Gambar 4. Tampilan Form Input Barang

Keterangan:

Pada form ini digunakan untuk pengimputan barang, cek stokis barang, pencarian barang sesuia dengan ID barang atau dengan mengunakan nama barang sekaligus, dan juga sudah di tambahkan kolom jenis barang dan stok barang

Tampilan Form Transaksi arang

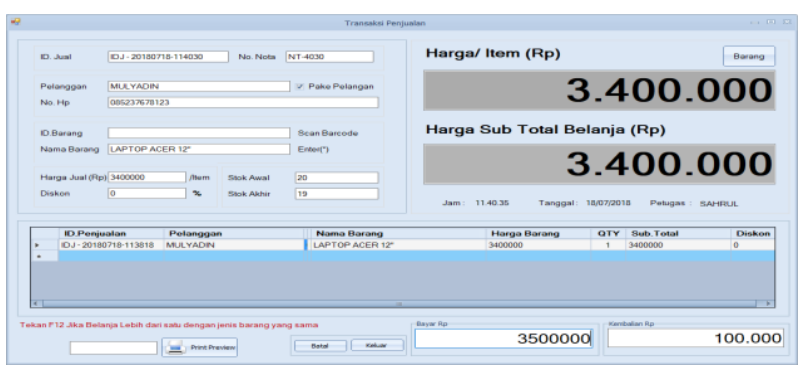

Gambar 5. Tampilan Form Transaksi

Keterangan:

Pada form ini digunakan untuk melakukan proses transaksi penjualan yang dimana sudah disediakan kolom sesuai kebutuhan. Contohnya:

a. Kolom id penjualan berfungsi untuk menjadi identitas transaksi penjualan.

b. Kolom nota transaksi yang berfungsi untuk penomoran nota.

c. Kolom pelanggan untuk identitas pelangan yang melakukan transaksi di toko tersebut.

d. Kolom id barang yang berfungsi untuk menginput id barang yang akan dijadikan transaksi, dengan hanya menginput $i d$ barang akan otomatis menampilkan data barang dengan id tersebut.

e. Kolom harga/item untuk menampilkan harga per item-nya, kolom sub total untuk menampilkan jumlah belanja semua item.

f. Kolom bayar berfungsi untuk penginputan jumlah uang yang dan kolom kembalian akan secara otomatis menampilkan jumlah uang yang lebih dari harga barang.

g. Kolom print previw ialah berfungsi untuk memasukkan id nota agar dapat dicetak sesuai nota transaksi.

\section{Tampilan Nota Otomatis Hasil Penjualan}

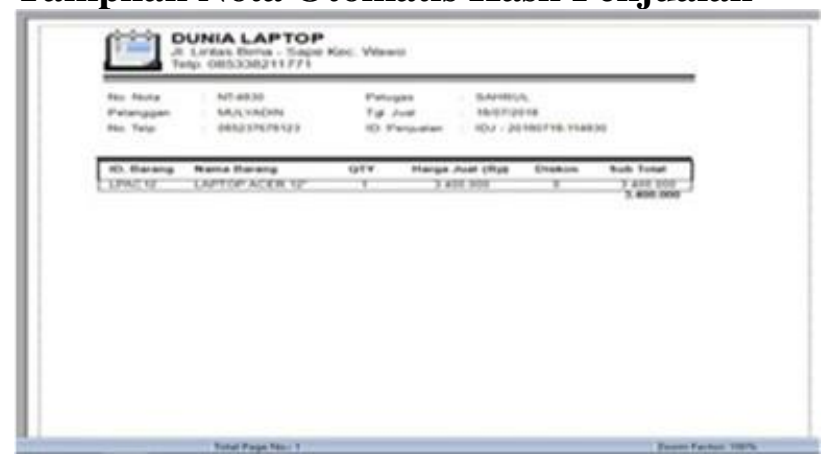

Gambar 6. Tampilan Nota Penjualan

Keterangan: 
Bagian ini berguna untuk mencetak nota hasil transaksi, di bagian ini sudah didesain khusus untuk penotaannya yang dimana sudah ditambahkan langsung nomor nota, nama pelangan, nomor telepon pelangan, nama petugas atau pegawai yang bertugas saat itu, tanggal transaksi, dan transaksi id penjualan.

\section{Tampilan Form Hasil Penjualan}

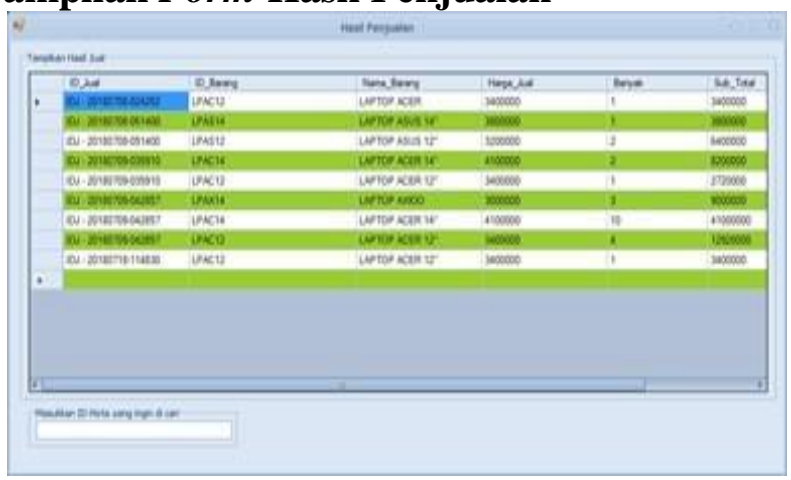

Gambar 7. Tampilan Hasil Penjualan

\section{Keterangan:}

Pada form ini berfungsi untuk melihat atau mengecek kembali hasil transaksi yang sudah dilakukan, di form ini juga sudah ditambahkan kolom pencarian secara otomatis yang hanya dengan megimput nama barang atau id barang yang akan dicari dan akan menampilkan secara otomatis data yang dicari tersebut.

\section{Tampilan Form Data Pelanggan}

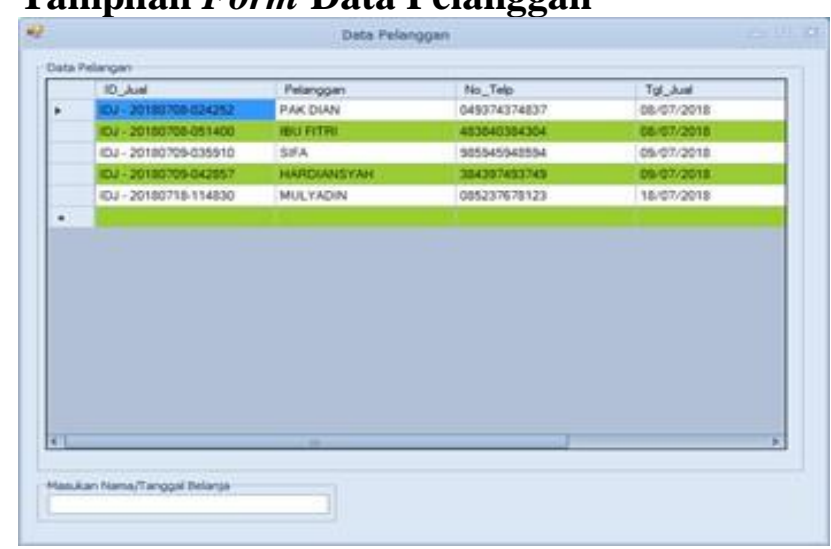

Gambar 8. Tampilan Data Pelanggan

\section{Keterangan:}

Form ini juga pada umumnya sama cara kerjanya dengan form tampil hasil penjualan, dan juga sudah ditambahkan kolom pencaraian yang digunakan pecarian data pelangan sesuai dengan nama dan nomor handpone-nya.

\section{Tampilan Laporan Bulanan / Tahunan}

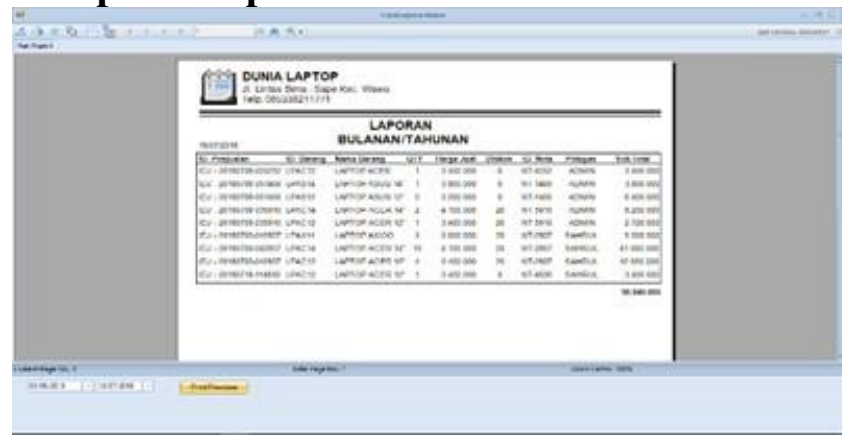

Gambar 9. Tampilan Laporan

Bulanan/Tahunan

Keterangan:

Pada bagian ini yaitu bagian tampilan laporan bulanan dan tahunan berguna untuk melihat omset perbulan maupun pertahunnya. Pada bagian ini sudah ditambahkan 2 (dua) Date Time Piker yang digunakan untuk menentukan tahun dan tanggal transaksi, jika ingin melihat omset setiap bulan tinggal disesuaikan dengan Data Time Piker yang pertama dan yang kedua begitupun dengan omset pertahunnya, data inipun bisa langsung dicetak.

\section{KESIMPULAN}

Kesimpulan yang dapat diperoleh pada penelitian pengembangan ini adalah:

1. Telah dikembangkan aplikasi transaksi penjualan di toko Dunia Laptop berbasis VB.Net 2010 untuk meningkatakan kelancaran proses transaksi di toko tresebut dengan karakteristik sebagai berikut:

a. Berisikan data admin yang dimana data tersebut akan digunakan untuk proses login di aplikasi ini.

b. Data stokis barang sudah dikembangkan dengan menampilkan secara langsung jenis barang dan stok barang, dan peneliti juga telah menambahkan tools pencari data barang yang dimana akan memudahkan dalam pencarian barang dalam jumlah besar.

c. Form transaksi ialah form untuk melakukan proses transaksi yang tidak dimiliki oleh aplikasi sebelumnya.

d. Nota penjualamn secara otomatis.

e. Laporan bulanan dan laporan tahunan yang berguna untuk melihat hasil penjualan pertahun atau perbulannya. 
2. Berdasarkan hasil uji coba terhadap aplikasi transaksi penjualan di toko Dunia Laptop berbasis VB.Net 2010 dapat dipaparkan sebagai berikut:

a. Hasil validasi dari ahli materi pada aplikasi transaksi penjualan dengan subtema tampila dan isi mencapai ratarata kelayakan mencapai 4,5 yang artinya aplikasi ini sangat baik (SB) digunakan.

b. Hasil validasi dari ahli media pada aplikasi transaksi penjualan di toko Dunia Laptop subtema tampilan dan isi mencapai rata-rata kelayakan 4,6 yang artinya aplikasi ini Sangat Baik (SB) digunakan.

c. Hasil penilaian uji kelompok kecil terhadap 2 item barang di toko Dunia Laptop pada aplikasi transaksi penjualan berbasis VB.net 2010 subtema judul dan proses transaksi mencapai rata-rata kelayakan 4,5 yang artinya aplikasi ini Sangat Baik (SB) digunakan.

d. Hasil penilaian uji kelompok besar terhadap 5 item barang di toko Dunia Laptop pada aplikasi transaksi penjualan berbasis VB.net 2010 subtema judul dan proses transaksi mencapai rata-rata kelayakan 4,5 yang artinya aplikasi ini Sangat Baik (SB) digunakan.

Berdasarkan rata-rata kelayakan pencapaian dari validitas ahli, uji skala kecil dan uji skala besar menujukkan bahwa aplikasi transaksi penjuakan di toko Dunia Laptop berbasis VB.Net 2010 sangat layak digunakan.

\section{DAFTAR PUSTAKA}

Assauri, Sofjan. (2004). Manajemen Pemasaran. Jakarta: Rajawali Press.

Dhanta, Rizky. (2009). Pengantar Ilmu Komputer. Surabaya: Indah.

Fata, Zayinul. (2010). Analisis Faktor-Faktor Yang Mempengaruhi Pendapatan Pedagang Batik (Studi Kasus di Pasar Klewer, Solo, Jawa Tengah). Tesis Universitas Sebelas Maret Surakarta.

Hendri, Ma'ruf. (2005). Pemasaran Ritel. Jakarta: Gramedia Pustaka Utama.
Junaedi, F. (2005). Panduan Lengkap Pemograman PHP untuk Membuat Web Dinamis. Yogyakarta: Anindya.

Mankiw, 2007. Makro Ekonomi, Edisi ke-6. Jakarta: Erlangga.

Nazruddin, Safaat H. (2012) (Edisi Revisi). Pemograman Aplikasi Mobile

Smartphone dan Tablet PC Berbasis Android. Bandung: Informatika.

Nitisemito, M. (1998). Manajemen Personalia. Jakarta: Erlangga.

Nursal. (2007). Panduan Visual Basic 1. Jakarta: Dinamika Ilmu.

Stefano. (2014). Cara Membangun Sistem Informasi Mengunakan VB.Net dan Komponen Dxperience. Yogyakarta: Andi Offset.

Sulhan. (2007). Pengembangan Aplikasi Berbasis Web dengan PHP dan ASP. Yogyakarta: Gava Media. 